\title{
FOIA: Then and Now
}

\author{
Sami Kerzel
}

$E^{\prime}$ nacted in 1966 and effective July 4, 1967, the Freedom of Information Act (FOIA) gives people, both citizens and non-citizens, the right to request access to federal executive branch agency records. ${ }^{1}$ According to FOIA's website, provided by the United States Department of Justice, FOIA "is a law that gives you the right to access information from the federal government. It is often described as the law that keeps citizens in the know about their government." ${ }^{2}$ However, agencies may at their own discretion provide access to records that fall under these exemptions and exclusions when allowed by law. ${ }^{3}$ Due to amendments that have occurred overtime, FOIA remains relevant in today's technological world. Some information, called proactive disclosures, are made freely available online by agencies, which do not require a request, and when requests are needed they can be made electronically. ${ }^{4}$ To truly understand FOIA an understanding of its general workings, amendment history and recent legislation is beneficial.

While the idea of a citizen's right to information was not new, due to the Administrative Procedure Act of 1946, ${ }^{5}$ a decade of debate among a variety of interested parties produced FOIA. ${ }^{6}$ Many government officials criticized FOIA; they questioned the amount of government information it would make available, and even its effectiveness. ${ }^{7}$ Meanwhile, the press worried that loopholes in the statute would prevent access to information. ${ }^{8}$ Although having many reservations about FOIA, Former President Johnson issued a signing statement rather than a public event. In this statement, Lyndon B. Johnson noted, "There are some who have expressed concern that the language of this bill will be construed in such a way as to impair government operation." $\mathrm{He}$ continued, "I have always believed that freedom of information is so vital that only the national security, not the desire of public officials or private citizens, should determine when it must be restricted ... I sign this measure with a deep sense of pride that the United States is an open society." 10 This change in mindset was fueled by a growing need for such litigation.
The only reasons for nondisclosure are outlined in the Act's nine exemptions and three exclusions. ${ }^{11}$ While these have been amended since FOIA's conception, at the time they should have provided worried parties with a greater understanding and delivered some relief. Additional provisions even provide requesters the right to appeal refused fulfillments. While FOIA's early years were surrounded by conflict over information and access, the topic is still widely debated, as can be seen through the 279 pieces of legislation that have passed both chambers, 248 bills that have made it to the president, and 230 bills that have become public law related to information issues since $1973 .{ }^{12}$ At the heart of keeping FOIA current and applicable are its amendments, which started with the first in 1974 and has seen a continued trend up until today.

FOIA's first amendment in 1974 narrowed exemptions relating to law enforcement and national security, and expanded provisions for requesters "relating to fees, time limits, segregability, and in camera inspection by the courts." ${ }^{13}$ This first major amendment was partially a reaction Watergate, and the abuses of power that occurred. During the same year the Privacy Act of 1974 was enacted, which partially supplements FOIA by establishing guidelines when requests by an individual seeking information about themselves. ${ }^{14}$ Essentially, the Privacy Act guarantees the right to see records about yourself, to amend records if they are outdated or wrong, and to use the government for any violations. ${ }^{15}$ As the government compiles a wide range of information on individuals, additional controls outlining what is gathered, how it is stored, and how it is used simply provides the public with security. Smaller amendments continued throughout the 70 s and early 80 s. These amendments focused on limiting what could be withheld as disclosure, ${ }^{16}$ technical changes relating to administrative disciplinary proceeding, ${ }^{17}$ and repealing expedited court-review. ${ }^{18}$

The second major amendment to FOIA occurred when the Freedom of Information Reform Act of 1986 was enacted by Congress. After two decades of experience this reform clarified the information accessible in relation to law enforcement 
and national security by expanding exemptions for law enforcement information, and law enforcement record exclusion. ${ }^{19}$ Additionally, this amendment created a new fee and waiver structure to reflect different types of requesters, creating appropriate cost levels. Ten years of continued use and practice followed the 1986 amendment, a long period of relative quietness compared to the decade before when FOIA was constantly evolving.

Eventually, technical growth during the late 80 s and 90 s, via accessible personal computers and beginning of the internet, caught up with FOIA through the Electronic Freedom of Information Act Amendments (EFOIA) of $1996 .{ }^{20}$ EFOIA brought FOIA into the twenty-first century by requiring the access of certain information electronically via FOIA Reading Rooms on the agency websites. Due to its online nature, EFOIA addresses "the difficult problem areas of compliance with the Act's time limits and administrative backlogs at many federal agencies, among other procedural issues." ${ }^{21}$ This amendment increased the amount of time for initial response to twenty days from twenty days, but tightened what is considered "exceptional circumstances," and allowed for a requester to demonstrate compelling need for materials. Also, denial notification now required denied records to be numerically specified. ${ }^{22}$ This amendment was a huge change for FOIA and forced many agencies into the twenty-first century, while others were already embracing it.

After the September 11 terrorist attacks, FOIA was amended through the Intelligence Act of $2003 .{ }^{23}$ This amendment limited the ability of the foreign intelligence community (i.e., foreign governments, international governmental organizations, intelligence agents, etc.) to either directly or indirectly request information via FOIA. ${ }^{24}$ Prior to this amendment any one, whether they were a U.S. citizen or not, could submit a request via FOIA. Amendments such as this, while reactive, maintain the relevance and importance of FOIA in today's government information climate.

Along a similar vein as the 1996 amendment, the OPEN Government Act of 2007 addressed many procedural issues. Essentially, the OPEN Government Act focused on fixing the FOIA system by specifically targeting delay and lack of responsiveness from agencies. ${ }^{25}$ Enhanced online access assisted with the receiving and responding to requests; however, technology didn't stop growing just for FOIA. Some changes included a

definition of news media requesters; the recovery of attorney fees and litigation costs; computing and tolling (or stopping) the time limits for responding to requests; tracking requests; agency annual reporting requirements; Attorney General and Special Counsel reporting requirements; treatment of agency records maintained by government contractors; creation of a new office in NARA; codification of the key roles played by Chief FOIA Officers and FOIA Public Liaisons; and new marking requirements for documents. ${ }^{26}$

While not all of these are directly related to technology and online advancements, one can see an increased technological aspect in many of these provisions. Continuing to adapt and push the system, rather than settling with whatever is at hand, allows FOIA to hold a greater impact and relevance in modern society.

Over FOIA's history there have been times of reform and practice; both of which are spurred by events, technology, and often people. Both former President Clinton and President Obama are known for their push towards openness in government information. Former President Clinton called for agencies to embody the spirit and primary objective of the Act, and reminded agencies "The statute was enacted based upon the fundamental principle that an informed citizenry is essential to the democratic process and that the more the American people know about their government the better they will be governed." ${ }^{27}$ President Obama believes that FOIA should be administered believing that "In the face of doubt, openness prevails," and "that agencies should take affirmative action to make information public ... not wait for specific requests from the public." ${ }^{28}$ This last thought is one that embodies the ideas behind the EFOIA and OPEN Government amendments, which push for more widely accessible and available information.

Unfortunately, not every voice in the current landscape is as welcoming. In fact, FOIA amendments often are met with hostility, and an unwillingness to bend to another party's agenda. While specific proposed amendments in recent years have been championed by bipartisan leadership, the unwillingness to work across the aisle in the larger houses has led to the failure of FOIA amendments. The Electronic Frontier Foundation notes, "It is becoming something of an annual tradition for Congress to introduce FOIA legislation with overwhelming bipartisan support," ${ }^{29}$ only to be shot down by one house or the other. This is unsurprising when noting that in recent years Congress has not been good at passing bills. In fact, the 113th Congress, known as "The Fighting 113th," was the "least productive ever." 30

During the 113th Congress the FOIA Improvement Act of 2014 and the FOIA Oversight and Implementation Act of 2014 
were proposed and died. Both houses passed their representative bills, ${ }^{31}$ but leaders in both house failed to put legislation to vote before adjourning for the summer. These amendments would have codified President Obama's open government directive. Both amendments received push back from the Department of Justice (DOJ) who believed the language used would allow for more frequent lawsuits on part of the requester. ${ }^{32}$ Interestingly, the DOJ oversees government wide FOIA compliance, and one might imagine they would be happy about much needed reform. ${ }^{33}$ Many politicians were surprised House republicans, especially House leader John Boehner, let a bill go unsigned that would have given the people greater oversight powers, especially since they have been interested in overseeing the Obama administration. ${ }^{34}$ Both amendments failed due to minimal differences within their text, and specific agendas, even though more than seventy groups backed the Senate bill.

Currently, during the 114th Congress there are two bills with familiar titles: the FOIA Improvement Act of 2016 and the FOIA Oversight and Implementation Act of 2016. ${ }^{35}$ Both originated from the former legislation introduced during the 113th Congress. The FOIA Improvement Act was approved by was passed by the Senate on March 15, 2016, and the FOIA Oversight and Implementation Act was passed by the House on January 11, 2016. Both bills are waiting to be signed by the House and Senate, respectively. The next step is to settle differences between both bills without a conference committee, where the bill has a greater chance of dying. ${ }^{36}$ July 4, 2016, marks FOIA's fiftieth anniversary, at which point FOIA advocates hope to see a final bill set forth by Congress ready for the President to sign. ${ }^{37}$

As a whole, the Senate bill reaffirms an openness in government. The bill addresses deficiencies in Federal agency FOIA request responses, since many agencies are resisting responding to requests, creating a substantial backlog and leading to expensive litigation. ${ }^{38}$ Specifically, the bill addresses this issue by prohibiting withholding records unless it would harm an interest protected by FOIA exemptions or outlined in other statutes, and limiting exemption 5, which is often referred to as the "withhold it because you want to" exemption. ${ }^{39}$ Internal agency deliberations would no longer be able to be withheld if they were older than twenty-five years. Unfortunately, this new provision doesn't go far enough, because it excludes a broader document base, which is often excluded by misuse of exemption $5 .{ }^{40}$ Also, the bill states that fees cannot be charged if the request is not fulfilled within the twenty-day deadline, adding protection for requesters. ${ }^{41}$ Finally, brining FOIA into a more modern twenty-first century, the bill provides for a central online FOIA request portal. Overall, unlike the House bill, the Senate's bill does not provide for greater secrecy for national security agencies, but rather promotes greater transparency across the federal government. ${ }^{42}$

The House bill is only slightly different from the Senate's bill; however, hopefully these differences won't produce another stalemate like past litigation. This bill also increases transparency and accountability in government; however, goes a step further than the Senate bill by codifying government openness. ${ }^{43}$ Also, the House bill expands the provisions to exemption 5 by including all documents in the twenty-five-year sunset limitations, which like the Senate bill would hold the force of law over agencies withholding unnecessary documents. ${ }^{44}$ Holding federal employees to this amendment, an additional provision states that annual performance evaluations must measure the responsibility and responsiveness to FOIA requests for each employee. ${ }^{45}$ Additionally, the bill would make it easier for Courts to award attorney's fees to requesters who sue based on denial of requests. ${ }^{46}$ Unfortunately, the bill only brings some agencies into the twenty-first century by requiring all agencies to accept requests via email. ${ }^{47}$ Also, there are a few provisions that allows for greater secrecy especially concerning intelligence agencies, something that has been troubling to US citizens after learning more about mass surveillance activities. ${ }^{48}$ While FOIA already has an exemption which protects classified materials, this new provision would prohibit the disclosure of materials which negatively impact intelligence sources and methods, but the language is incredibly vague, which would allow agencies greater nondisclosure. Another provision exempts intelligence agencies from having to disclose documents not provided due to being prohibited by law, and would not need to inform requesters when they consult with other agencies, due to materials being generated by the other agency. Essentially, these additional provisions restrict government transparency in ways that prevent citizens from knowing more about their government.

The Senate and House bills are attempting to bring greater transparency, although they both limit transparency relating to certain materials or agencies. Currently, FOIA legislation is pushed by a broken FOIA system, which often focuses on small issues rather than larger, big picture ideas. ${ }^{49}$ During 2015, 14.41 percent of request were backlogged or not responded to, 59.29 percent of requests were released in part, and 7.28 percent of requests were completely denied. ${ }^{50}$ Simply looking at these statistics one can see there are issues with the system. FOIA's effectiveness has been maintained by continued amendments throughout its fifty years; unfortunately, current politicians have yet to come to an agreement on how to continue to improve FOIA and 
provide for continual relevance. As many Presidents and politicians have noted, the rights FOIA provides are central to the rights of Americans and continued growth of America.

Sami Kerzel (sami.kerzel@osucascades.edu), Library Support Staff at Oregon State University-Cascades.

\section{References}

1. 5 USC \$ 552; US General Services Administration, Your Right to Federal Records: Questions and Answers on the Freedom of Information Act and the Privacy Act (Washington, DC: US Dept. of Justice, GSA Office of Citizen Services and Communications, Federal Citizen Information Center, 2004), i.

2. "What is FOIA?," US Department of Justice, www.foia .gov/index.html.

3. US Department of Justice, Your Right to Federal Records, i.

4. US Department of Justice, "Proactive Disclosures," last modified July 29, 2014, https://www.justice.gov/oip/ proactive-disclosures.

5. 5 USC \& 1002 (1964).

6. 112 Cong. Rec. H13641-42 (daily ed. June 20, 1966).

7. Benny L. Kass, "The New Freedom of Information Act," American Bar Association Journal 53, no 7 (1967): 667.

8. Ibid.

9. Availability of Government Records and Information, 2 Weekly Comp. Pres. Docs. 895 (July 11, 1966).

10. Ibid.

11. 5 USC $\$ 552$.

12. "Freedom of Information, Legislation," Congress.gov, last modified May 29, 2016, https://www.congress.gov/.

13. Pub. L. No. 93-502, 88 Stat. 1561; US Department of Justice, Department of Justice Guide to the Freedom of Information Act (Washington, DC: US Dept. of Justice, 2009), 5.

14. "Freedom of Information Act Guide, September 1998," FindLaw, last modified May 25, 2016, http:/corporate .findlaw.com/litigation-disputes/freedom-of-information -act-guide-september-1998.html.

15. US Deptartment of Justice, Your Right to Federal Records, i.

16. 5 USC \$552b.

17. 5 USC $\$ 552(\mathrm{a})(4)(\mathrm{F})$.

18. 28 USC \$ 1657 (2006).

19. "Freedom of Information Act Guide, September 1998."
20. Pub. L. No. 104-231, 110 Stat. 3048.

21. US Department of Justice, "Senate Advances Electronic FOIA Bill," FOIA Update 17, no. 2 (1996), https:// www.justice.gov/oip/blog/foia-update-senate-advances -electronic-foia-bill.

22. US Department of Justice, "Senate Advances Electronic FOIA Bill."

23. Pub. L. No. 107-306, 116 Stat. 2383 (2002).

24. US Department of Justice, Department of Justice Guide, 6. 25. Pub. L. No. 110-175, 121 Stat. 2524.

26. US Department of Justice, Department of Justice Guide, 7. 27. US Department of Justice, "Memorandum for Heads of Departments and Agencies," FOIA Update 14, no. 3 (1993), https://www.justice.gov/oip/blog /foia-update-president-clintons-foia-memorandum.

28. President Obama's FOIA Memorandum, 74 Fed. Reg. 15, 4683 (Jan. 26, 2009).

29. Josh Hicks, "How a Popular Government-Transparency Bill Suddenly Died in Congress," Washington Post, December 16, 2014, https:/www.washingtonpost.com /news/federal-eye/wp/2014/12/16/how-a-popular-gov ernment-transparency-bill-suddenly-died-in-congress/.

30. Philip Bump, "The 113th Congress is Historically Good at Not Passing Bills," Washington Post, July 9, 2014, https://www.washingtonpost.com/news/the-fix/wp/2014 /07/09/the-113th-congress-is-historically-good-at-not -passing-bills/.

31. S. 2520, 113th Cong. (2014); H.R. 1211, 113th Cong. (2014).

32. Josh Hicks, "How a Popular Government."

33. Lauren Harper, "Overall Good FOIA Reform Bill Passes House With Troubling IC Carve-Outs: FRINFORMSUM," National Security Archive, January 14, 2016, https://nsarchive.wordpress.com/2016/01/14/overall -good-foia-reform-bill-passes-house-with-troubling-ic -carve-outs-frinformsum-1142016/.

34. Josh Hicks, "How a Popular Government."

35. S. 337, 114th Cong. (2016); H.R. 653, 114th Cong. (2016).

36. Steven Aftergood, "House Poised to Pass FOIA Amendments," Federation of American Scientists, January 11, 2016, https://fas.org/blogs/secrecy/2016/01/house-foia/.

37. "Senate Approves FOIA Reform Bill; Setting up Conference with House," Newspaper Association of America, last modified March 16, 2016, http://www.naa.org/Public -Policy/Government-Affairs/First-Amendment/Senate -Approves-FOIA-Reform-Bill.aspx.

38. Ibid. 
39. Aaron Mackey, "Fixing FOIA: Senaate-Passed Bill is a Good Start, but More is Needed," Electronic Frontier Foundation, last modified March 16, 2016, https:// www.eff.org/deeplinks/2016/03/fixing-foia-senate-passed -bill-good-start-more-needed.

40. Mackey, "Fixing FOIA."

41. Ibid.

42. Ibid.

43. Aftergood, "House Poised to Pass FOIA Amendments." 44. Mackey, "Fixing FOIA."

45. "Senate Approves FOIA Reform Bill."
46. Aaron Mackey, "Here's How the Senate Should Fix the FOIA Reform Bill," Electronic Frontier Foundation, last modified Jan. 15, 2016, https:/www.eff.org/deep links/2016/01/heres-how-senate-should-fix-foia-reform -bill.

47. Mackey, "Here's How the Senate."

48. Ibid.

49. Ibid.

50. "What is FOIA?" 